\title{
The Future of e-Voting. Some Remarks from the Perspective of the Polish Law
}

Beata Stępień-Zatucka <beata@kpmz.pl>

RZESZÓW, Poland

\section{Abstract}

The life of modern man is different from that of twenty or even ten years ago. Over the Internet, we work, we talk, we do our shopping, we check our account balance, we pay, but we still do not vote, and yet elections are the basis of democracy. The introduction of Internet voting, especially in times of pandemics, has shown that it is our future. However, its introduction requires further obstacles to be overcome, both legal and technical. In this paper, I will present the legal requirements that e-voting would have to meet, from the perspective of the validity of the electoral principles contained in the Constitution. At the same time, I will present arguments indicating that the introduction of e-voting will not require amendments to the Constitution of the Republic of Poland, but only changes to the Electoral Code concerning the way of voting. In terms of the technical requirements that e-voting would have to meet, I will point to the problems and shortcomings revealed in the countries that have decided to introduce e-voting. Observing revealed errors and shortcomings in the operation of e-voting in other countries is a natural way to prevent them in Poland. Addressing these problems will allow us to avoid the mistakes that other countries introduction of e-voting.

\section{Introduction}

Elections are the foundation of democracy. ${ }^{1}$ They allow the society to choose representatives who will exercise power on its behalf.

1 Joseph L. Hall, Policy Mechanisms for Increasing Transparency in Electronic Voting, (Barkeley 2008) $11<$ https://josephhall.org/papers/jhall-phd.pdf > accessed 30 June 2021. 
This process currently takes different forms, sometimes based on the traditional method of casting a vote on a piece of paper, or it reaches more innovative forms such as e-voting, which means electronic voting, which is a collective term for a form of voting using electronic means of communication. This can be divided into three types of voting: electronic visualization of voting results, electronically assisted voting (voting machines) and Internet voting, which, like the entire section, is also sometimes referred to as e-voting (or Internet voting, ivoting, e-voting: full, complete, proper). This type of voting is characterized by the fact that votes are cast remotely over the Internet, from any location, and are received and counted by a central computer election system. ${ }^{2}$

Nowadays, when the world faces a pandemic, it has become clear that the current form of voting, let's call it - paper-based, in the long run will require changes in the on-line direction. This direction raises questions firstly about the legal, social, technical requirements and secondly about the risks associated with its introduction.

In this article I will present the legal framework related to the possible introduction of e-voting in Poland and I will bring closer the problems faced by the countries that have already introduced e-voting, so that the possibly introduced form in Poland will contain technical answers to them. Their technical elimination will make it possible not to repeat the doubts and mistakes that have already been overcome or with which other countries are still struggling.

We must remember that e-voting is still associated with innovation, which is followed by new solutions, but also hitherto unknown problems, both legal and otherwise.

2 Beata Stępień-Załucka, 'E-voting. Sukces czy porażka na przykładzie Estonii i Szwajcarii' in Paweł Kuczma (ed) Aktualne wyzwania demokracji partycypacyjnej w Polsce $i$ na świecie (Wydawnictwo Uczelni Jana Wyżykowskiego) 2017244. 


\section{Definition of e-voting}

E-voting ${ }^{3}$ is a collective term for a form of voting that uses electronic means of communication. ${ }^{4}$ This form of voting can be divided into three types of electronic voting:

- electronic visualization of voting results. In this form, computer systems play an auxiliary role in collecting and visualizing the results of voting conducted by traditional means; 5

- electronically assisted voting, in which case computer systems are the main tool for receiving and counting votes. Votes are cast by voters in person at polling stations on specialized voting machines. ${ }^{6}$ Such

3 I wrote more about that in: Beata Stępień-Załucka E-voting a Konstytucja RP in Jerzy Jaskiernia and Kamil Spryszak (eds) Dwadzieścia lat obowiazywania Konstytucji RP. Polska myśl konstytucyjna a międzynarodowe standardy demokratyczne (Wydawnictwo Adam Marszałek 2017) 223-225.

4 Andreu R. Jorba, Josè A. Ortega Ruiz and Paul Brown, 'Advanced Security to Enable Trustworthy Electronic Voting' (2003) Scytl Online World Security 2-3 $<$ https://www.scytl.com/wp-content/uploads/2013/04/Advanced-Security-to-EnableTrustworthy-Electronic-Voting.pdf $>$ accessed 30 June2021]; Lilian Mitrou, 'Constitutional And Legal Requirements For Evoting' (2004) Electronic Voting Observatory II Votobit (Leon, 3-4.10.2004) 2 ff. <http://www.Icsd.Aegean.Gr/Website_Fil es/Metaptyxiako/65983061.Pdf > accessed 30 June2021; Lelia Barlow, An Introduction to Electronic Voting, 2003, 2-13 < http://citeseerx.ist.psu.edu/viewdoc/download? doi=10.1.1.136.2993\&rep=rep1\&type=pdf $>$ accessed 30 Jue 2021.

5 International Idea. International Institute for Democracy and Electoral Assistance: Peter Wolf, Rushdi Nackerdien and Domenico Tuccinardi, Introducing Electronic Voting: Essential Considerations (IDEA 2011) $7<\mathrm{http}: / / \mathrm{www} . \mathrm{idea} . \mathrm{int} / \mathrm{publications/int}$ roducing-electronic-voting/upload/PP_e-voting.pdf $>$ accessed 30. June 2021.

6 Barbara Simons, 'Electronic Voting Systems: the Good, the Bad, and the Stupid' (2004) 2, 7 QUEUE 3-11.

$<$ http://www.openvotingconsortium.org/files/voting_good_bad_stupid.pdf > accessed 30 June2021.More about that, Ben Goldsmith and Holly Ruthrauff, 'Chapter 2.3: Implementing Electronic Voting or Electronic Counting in an Election Lead' in NDI and IFES, Implementing and Overseeing Electronic Voting and Counting Technologies (2013) $36 \mathrm{ff} .<$ https://www.ndi.org/files/2.3.pdf> accessed 30 June 2021. IFES, 'Electronic Voting Machines (EVMs), „Pakistan Factsheet'(IFES, 2014) 1-5, $<$ https://www.ifes.org/sites/default/files/electronic_voting_machines.pdf $>$ accessed 30 June 2021. 
a system can be found in Australia, Brazil, Canada, France, ${ }^{7}$ India, ${ }^{8}$ Japan, Kazakhstan, ${ }^{9}$ Peru, Russia, the United States, the United Arab Emirates and Venezuela; ${ }^{10}$

- voting via the Internet (due to the fact that it is currently the most complete form of electronic voting available, it is also generally referred to as -ivoting, e-voting, e-voting proper, full, complete, Internet voting). This type of voting occurs when votes are cast remotely from any location via the Internet ${ }^{11}$ and are received and counted by a central computerized election system. ${ }^{12}$ This is the case in Estonia and Switzerland, ${ }^{13}$ for example, and a number of countries have non-binding plans, with varying degrees of progress, to implement it. Among them are Argentina, Azerbaijan, Belarus, Bulgaria, Chile, Czech Republic, Finland, Greece, Italy, Latvia, Lithuania, Mexico, Nepal, Nigeria, Norway, Portugal, Romania, Slovakia, Slovenia, South Africa, Spain, South Korea and Sweden. ${ }^{14}$ The diffusion of Internet voting is currently growing fastest in Canada and Norway. ${ }^{15}$ It is also worth nothing that while some countries are planning to implement e-voting, others, for

7 Jordi B. Esteve, Ben Goldsmith and John Turner, 'International Experience with E-Voting. Norwegian E-Vote Project' (IFES, 2012) $12<$ https:/www.parliament.uk /documents/speaker/digital-democracy/IFESIVreport.pdf> accessed 30June 2021.

8 ScottWolchok, Eric Wustrow, J. Alex Halderman, Hari K. Prasad, Arun Kankipati, Sai Krishna Sakhamuri, Vasaya Yagati and Rop Gonggrijp, 'Security Analysis of India's Electronic Voting Machines' (2010) CCS . 1-14, <https://jhalderm.com/pu b/papers/evm-ccs10.pdfs accessed 30June 2021.

9 Douglas W. Jones, 'Kazakhstan: The Sailau E-Voting System' in Michael Yard (ed) Direct Democracy: Progress and Pitfalls of Election Technology 4-6 <http://homepage.c s.uiowa.edu/ jones/voting/IFESkazakhstan.pdf > accessed 30 June 2021.

10 The Electoral Knowledge Network, 'E-voting' <http://aceproject.org/ace-en/focus/ e-voting/countries> accessed 30 June 2021.

11 Andrzej Kisielewicz, Komentarz do art. 2 Kodeksu wyborczegoin Kazimierz W. Czaplicki, Bogusław Dauter and others, Kodeks wyborczy Komentarz LEX (Wolters Kluwer 2014) 22.

12 Kazimierz W. Czaplicki, 'Alternatywne sposoby głosowania. (Zarys problemów)' in Sabina Grabowska and Radosław Grabowski (eds) Międzynarodowa konferencja naukowa. Alternatywne sposoby gtosowania a aktywizacja elektoratu. Rzeszów 26-27 marca 2007 r., 29.

13 The Electoral Knowledge Network, E-Voting, <http://aceproject.org/ace-en/focus/e -voting/countries>, [Access by day 30.06. 2021].

14 ibid.

15 Alexander $\mathrm{H}$ Trechsel, Can introducing the internet as a means of casting votes lead to distortions in the political sphere? How neutral is this new technology? Seminarium from 4th February 2013, described by Rosie Scammell, 'Internet voting a success in two European countries' (European University Institute, 12 February 2013) 
various reasons, are at the stage of stopping projects of its implementation. These include Germany, Ireland, the Netherlands and the United Kingdom. ${ }^{16}$ And it is this type of voting that will be the subject of further consideration.

\section{Standards and regulations that e-voting has to face}

The answer to the question, which is the title of the subsection, is contained in H. Kelsen's pyramid. According to its idea, all legal acts must be consistent with the highest one - the Constitution. ${ }^{17}$ In this case, it is important to note that the Constitution of the Republic of Poland does not indicate the form of conducting elections. E-voting as a method of voting would be determined at the level of the election code, i.e. the law. Therefore, while e-voting would be consistent with the constitutional election principles, i.e. universality, equality, directness, proportionality and secrecy of voting, as well as the sometimes overlooked principle of free elections, its possible introduction would not require a change to the Constitution. The only change would be made at the level of the law. At the same time, this compliance with electoral principles is important because their implementation is a condition sine qua non for recognising the validity of elections. Therefore, their non-fulfilment automatically translates into a lack of democracy in filling the seats in representative bodies and leads to invalidation of the elections by the Supreme Court. ${ }^{18}$

Implementation of the principle of universality of elections will boil down to guaranteeing all eligible persons the opportunity to vote, but also to overcoming the problem of digital exclusion, i.e. the lack of equal opportunities in access to the Internet, information and communication

$<$ http://www.eui.eu/News/2013/02-12-InternetvotingasuccessintwoEuropeancount ries.aspx $>$ accessed 30 June 2021.

16 The Electoral Knowledge Network, E-voting, http://aceproject.org/ace-en/focus/ e-voting/countries, [Access by day 30.06. 2021]; Tadayoshi Kohno, Adam Stubblefield, Aviel D. Rubin and Dan S. Wallach, 'Analysis of an Electronic Voting System' (IEEE 2004) 3-7 <http://avirubin.com/vote.pdf> accessed 30 June 2021. More about that, Beata Stepień-Załucka, 'E-voting. Sukces czy porażka na przykładzie Estonii i Szwajcarii'in Paweł Kuczma (ed) Aktualne wyzwania demokracji partycypacyjnej w Polsce i na świecie (Wydawcnitwo Uczelni Jana Wyżykowskiego 2017).

17 Mirosław Granat, Prawo konstytucyjne w pytaniach $i$ odpowiedziach, (LexisNexis 2010) 40 .

18 I wrote more about that in (n 3) 223-225. 
technology (ICT) infrastructure, or computer skills. ${ }^{19}$ Therefore, this form of voting, if introduced, could be only optional in relation to the traditional voting method. Internet voting requires also compliance with the criterion of equality, which in the case of e-voting would boil down to the necessity to exclude the risks associated with the possibility of multiple voting, family voting, forced voting, voting by a non-voter and selling the vote, and at the same time to introduce technical solutions that would guarantee the casting of only one vote and protect against the possibility of repeated voting. Equality, on the other hand, should also guarantee the accessibility of the ballot in terms of access to it and the simplicity of voting. ${ }^{20}$ Another determinant of the constitutionality of Internet elections

19 Michał Wróblewski, 'Cyfrowy analfabetyzm ante windows? O wykluczeniu społecznym i projekcie DIGI.COM/YOUTH \#37’ (Medium, 31 January 2017) $<$ https://medium.com/@wiedziecwiecej/cyfrowy-analfabetyzmem-ante-windows-o -wykluczeniu-spo\%C5\%82ecznym-i-projekcie-digi-com-youth-406d4fadfecb\#.o003 zj2ma $>$ accessed 30 June 2021.

Henry E. Brady and Iris Hui, Accuracy and Security in Voting Systems, (Berkeley 2008) $1 \mathrm{ff} .<$ https://www.princeton.edu/csdp/events/Election050108/BradyElection .pdf $>$ accessed 30 June 2021.

20 Ibidem.

The American Congress countered the irregularities related to the Internet vote count in the 2000 presidential election with the HAVA law reforming the electoral process, signed by President Bush on 29 October 2002. Its essence was, on the one hand, an order to fund the replacement of outdated voting technologies such as punch cards and replace them with more modern ones such as optical scanners and electronic direct voting machines. On the other hand, and more importantly, HAVA included a requirement, allowing for voter identification in certain situations, to allow for manual audits of voting results, which directly implicated the inability of the voter and anyone else, in an audit, to verify to which candidate in 2000 their vote was actually attributed. A. Roseman, State constitutional lawequal protection - the Indiana Supreme Court's less than rational basis review of equal protection claims resulted in the validation of the Indiana voter id law. League of Women Voters of Indiana, inc. v. Rokita, 929 n.e.2d 758 (ind. 2010), (2013) 43, 2Rutgers Law Journal. $873 \mathrm{ff} .<$ http://lawjournal.rutgers.edu/sites/lawjournal.rutgers.ed u/files/issues/16RosemanVol.43.4_v3.pdf > accessed 30 June 2021. FinLaw's Team, 'Federal Voter ID Requirements: The Help America Vote Act (HAVA)' (Findlaw, 18 March 2021) <http://civilrights.findlaw.com/other-constitutional-rig hts/federal-voter-id-requirements-the-help-america-vote-act-hava.html $>$ accessed 30 June 2021.; Gloria Lin and Nicole Espinoza, 'Florida Congressional Elections: November 2006' (Standford 2007) <https:/cs.stanford.edu/people/eroberts/cs181/pro jects/2006-07/electronic-voting/index_files/page0004.html > accessed 30 June 2021; See too, New Study of E-Voting Effects in Florida, https:/freedom-to-tinker.com/ blog/felten/new-study-e-voting-effects-florida/;Study accessed 30 June 2021. Robert McMillan, 'finds e-voting irregularities in Florida' (Computerweekly.com, 
is directness. ${ }^{21}$ In the practice of online elections, this principle would be realized through the direct registration of the ballots online, but the counting of the ballots would have to take place at the very end of the voting procedure so as to eliminate any possible influence of the knowledge of the partial results on the turnout and the final outcome of the election. ${ }^{22}$ The principle of proportionality in the case of e-voting is the least relevant to a possible claim of constitutionality, since while this method of voting allows for the establishment of accurate data, the distribution of seats obtained on the basis of such data is carried out by means of a specific distribution method. In Poland, this is the d'Hondt method. ${ }^{23}$ Another electoral attribute that e-voting would have to meet is the secrecy of the vote ${ }^{24}$ which in the case of Internet voting would have to guarantee the secrecy of the election at all stages and at the same time allow for verification of the vote cast, which would be particularly important in the case of situations such as selling votes or voting under pressure from other voters - parents or spouses. ${ }^{25}$ E-voting would also have to meet the requirements of the principle of free elections, guaranteeing each voter the ability to exercise his or her active and passive electoral rights without any physical or mental coercion or constraints, ensuring freedom of expression ${ }^{26}$ but

23 November 2004) <http://www.computerweekly.com/feature/Study-finds-e-voti ng-irregularities-in-Florida accessed 30 May 2021.

Mitrou (n 4) 8 ff. <http://Www.Icsd.Aegean.Gr/Website_Files/Metaptyxiako/6598 3061.Pdf $>$, accessed 30 June 2021.

21 Dorota Lis-Staranowicz, 'Kodeks wyborczy. Wyrok z dnia 20 lipca 2011 r., K 9/11', in Leszek Garlicki, Marta Derlatka and Marcin Wiącek (eds) Na straży państwa prawa. Trzydzieści lat orzecznictwa Trybunatu Konstytucyjnego (Wolters Kluwer 2016) 819-838.

22 Mitrou, (n 4)15. More about that, Gábor Toka, The impact of partial results on election, <http://www.personal.ceu.hu/staff/Gabor_Toka/Papers/Toka04Chicago.p df $>$ accessed 30 June 2021.

23 Jeremiasz Salamon, 'Polityczne konsekwencje wyboru metody dystrybucji mandatów na przykładzie elekcji do Sejmu RP z 21 października 2007 roku’ (2014) 4-5 Studia Politicae Universitatis Silesiensis 139 i n.

24 Blerim Rexha, Vehbi Neziri and Ramadan Dervishi, 'Improving authentication and transparency

of e-Voting system - Kosovo case' (2012) 1, 6 International Journal Of Computers And Communications 84 <http://www.universitypress.org.uk/journals/cc/17-858. pdf $>$ accessed 30 June 2021.

25 Mitrou (n 4) 12.

26 BartłomiejOpaliński, 'Wolność wyborów parlamentarnych i jej gwarancje na gruncie Konstytucji Rzeczypospolitej Polskiej' (2012) 2 Przegląd Prawa Konstytucyjnego $59 \mathrm{ff}$; http://www.marszalek.com.pl/przegladprawakonstytucyjnego/ppk1 0/03.pdf accessed 30 June 2021. 
also the possibility of casting an invalid vote, which is a kind of manifesto of the voter. ${ }^{27}$

\section{Threats connected with introduction of e-voting.}

Apart from changes in the Electoral Code, introduction of e-voting in Poland would also require elimination of threats to its operation noticed in practice in countries where this form of voting already works. Eliminating them, or at least minimizing them, will allow the system to operate without the errors that have been noticed.

The Netherlands is a country that has faced up to the shortcomings of e-voting. This country tried to conduct elections in the form of e-voting in 2008. The choice of this way of voting was aimed at increasing voter turnout, but it soon turned out that it contains shortcomings that undermine the integrity of elections. The first argument in favor of incorrect operation system concerned the encryption of the votes cast. According to the tests, the chosen encryption method protected the secrecy of the vote any for some time, in the best case, the votes will be secret until the end of 2030. However, the testers themselves stated that even before this date it will be possible to know the votes cast. In other words, it will become possible to know for whom a given voter voted. Another argument in this regard was the possibility of multiple voting. The election lasted 14 days, the system processed the vote for 20 hours, and this means that during the election, each voter could cast 16 defective votes. There were also concerns about the possibility of the system being hacked. Faced with these threats, on June 30, 2008, the Dutch government decided to halt certification of the system. ${ }^{28}$ The more so because another problem that arose concerned

27 An example of how important a role invalid votes can play in the electoral system can be Australia. More on this topic, Jessica Irvine, 'Informal vote makes mockery of democrasy'(smh.com, 28 August 2010) <http:/www.smh.com.au/federal-politi cs/informal-vote-makes-mockery-of-democracy-20100831-14fc3.html > accessed 30 June 2021. More on this topic: (n 3) $226 \mathrm{ff}$.

28 Leontine Loeber, 'E-voting in the Netherlands; past, current, future?' < https://ww w.researchgate.net/publication/301547849_E-voting_in_the_Netherlands_past_c urrent_future $>$ accessed 30 June 2021. More on that subject, Ben Goldsmith and Holly Ruthrauff, 'Implementing and Overseeing Electronic Voting and Counting Technologies. Case Study Report on Electronic Voting in the Netherlands'(NDI, 2013) 268-274 https://www.ndi.org/sites/default/files/Implementing_and_Oversee ing_Electronic_Voting_and_Counting_Technologies.pdf accessed 30 June 2021. 
the system's counting of so-called "air votes," i.e. votes that were included in the system even though they were not cast by voters. ${ }^{29}$

For years, Estonia has been an international model country that has implemented and in which functions on the basis of e-voting. In Estonia, e-voting is carried out by providing voters with a certificate (digital signature) with which they can vote on the website of the State Electoral Commission. The voter is thus identified by a digital signature. The choice is that once the voter is identified, the voting text is displayed to the voter on the website so that the voter can cast a vote. The voters are then informed on the website whether their vote has been added. ${ }^{30}$ It is important to note that voters can change their votes until the voting is complete, the last vote cast is the one that counts. ${ }^{31}$

Based on the above, it is necessary to note the following problem regarding voter identification. On the one hand, the Estonian voting mechanism consists of a password and an electronic signature that allow the voter to cast a ballot. On the other hand, this password and signature may not necessarily be used by the voter. One should be aware that both the password and the electronic signature can be used by third parties. So if Poland decided to go ahead with e-voting, the system would also have to face this threat. ${ }^{32}$

This raises another problem of how to verify the accuracy of the vote cast so that the secrecy of the ballot is not compromised. This is particularly true in systems which perform both voter authentication and vote casting. At this point, it should be noted that the system based on anonymity is not a solution to the above dilemma, because it completely eliminates any possibility of verifying the correctness of the system's operation. Thus, e-voting would remain beyond real control, which I find unacceptable. ${ }^{33}$

29 Krzysztof Skotnicki, Kilka słów o i-votingu, <http://repozytorium.uni.wroc.pl/Cont ent/89856/35_K_Skotnicki_Kilka_slow_o_i-votingu.pdf $>$ accessed 30 June 2021.

30 Michał Czakowski, 'E-voting na przykładzie Estonii i Brazylii' (2011) 3, 27 Studia BAS 130.

31 Daniel Lohrmann, 'Could Estonia Be the Model for Secure Online Voting?' (govtech.com, 25 September 2020) https:/www.govtech.com/blogs/lohrmann-on-cyb ersecurity/could-estonia-be-the-model-for-secure-online-voting.html accessed 30 June 2021.

32 Magdalena Musiał-Karg, 'Challenges of i-voting - practices, rules and perspectives. Examples from Estonia and Switzerland' (2017) 4, 17 Przegląd Polityczny $<$ http://przeglad.amu.edu.pl/wp-content/uploads/2018/07/pp-2017-4-06.pdf> accessed 30 June 2021.

33 Stępień-Załucka (n 3) 232. 
However, regardless of the lack of spectacular moments of failure Estonian of this system, there is a problem that cannot be completely eliminated - namely hackers. The risks associated with a hacking attack simply need to be, as much as possible, prepared for. ${ }^{34}$

This issue was vividly outlined in the 2020 elections in the United States. For it showed that the use of e-voting must go hand in hand with cybersecurity, the provision of which remains a major concern. This is because online voting opens the door to hackers collaborating, in the case of the aforementioned 2020 election, with U.S. opponents i.e. Russia and China. Skilled hackers can influence and manipulate the electoral outcome in their favor, several audits conducted against previous online U.S. elections, have shown, revealing many security vulnerabilities. For example, in 2020, "In February, MIT reported finding serious flaws in the online election system of Voatz, the company that ran the first mobile election in West Virginia, allowing a hacker to alter, stop or reveal a user's vote. Another study by MIT and the University of Michigan also found security problems with Omniballot, the system Delaware uses for online voting." 35

Cybersecurity experts emphasize that there is not and never will be a 100 percent guarantee for the security of any given website, app, or system. This is because every single one of these tools relies on humans to manage their software, and this makes it impossible to ever rule out the possibility that another human will break the software. The hacking of Twitter is a case in point. Another example is the operation of voting machines in the United States, which have repeatedly show to be not fully secure and a hacker is able to change, add or remove votes. ${ }^{36}$

With that said, beyond the hacking attack itself, e-voting is a system that also raises the risk of massive voter fraud. ${ }^{37}$ An example of this can be found in the literature on the use of electronic voter registration and voting systems in Alvarez and Hall in U.S., which pioneered the use of electronic voting and subsequently faced allegations of malicious software

34 Lohrmann (n 31).

35 Nathaniel Lee, 'Here's why most Americans are not able to vote online in 2020' (CNBC, 23 September 2020) <https://www.cnbc.com/2020/09/23/why-us-cant-vot e-online-in-2020-presidential-election-trump-biden.html> accessed 30 June 2021.

36 Jasmine Webb, 'Security Experts Say Online Voting Is a Bad Idea. Here's Why' (Digital Diplomacy, 20 July 2020), <https://medium.com/digital-diplomacy/secu rity-experts-say-online-voting-is-a-bad-idea-heres-why-1792c9a876b0 > accessed 30 June 2021.

37 Skotnicki (n 29). 
and hardware tampering. Another example is the anomalies revealed during the referendum in Venezuela in the state of Delta Amacuro, for which, after statistical studies, it was found that at different stages of the election the data differed and had a different distribution of turnout. Municipalities were singled out in this state that had a very large and out of bounds coefficient related to the proportion of "yes" votes. ${ }^{38}$

The experience of Ireland should also be kept in mind when introducing e-voting. In 2004, the government of this country purchased for about 50 million euros from a Dutch company specialized equipment Nedap, which was used in some constituencies. However, curiously, the Irish authorities responsible for the proper conduct of elections decided to order, an independent audit of the system's security. What transpired was that the auditing company questioned the quality of the security of the equipment purchased against potential fraud. As a result, the expensive pilot system became an expensive-to-maintain (generating annual maintenance costs running into hundreds of thousands of euros) digital dud. ${ }^{39}$

\section{Summary}

E-voting is one of the most modern instruments used in a democracy. Its introduction takes a country to a new, higher level of innovation and use of new technologies. However, its introduction is not only connected to legal changes, which in Poland would have to take place at the statutory level, as the basic regulations concerning the method of voting are still regulated at the statutory level, but also would have to overcome a number of technical problems that other countries have already faced or are still facing. These problems relate to issues such as security, the digital divide or, as the recent example shows, inadequate, excessive funding in relation to the product obtained, i.e. a system which, in the case of Ireland, proved to be flawed.

38 Inés Levin, Gabe Cohen, Peter Ordeshook and M. Alvarez, 'Detecting Voter Fraud in an Electronic Voting Context An Analysis of the Unlimited Reelection Vote in Venezuela' (2009) 83 Voting Technology Project

39 Marek Kowalski, 'Głosowanie przez internet - dlaczego jeszcze nie w Polsce? Korzyści i zagrożenia związane z wyborami elektroncznymi’ (Softonet.pl, 25 October 2015 ) <https://softonet.pl/publikacje/poradniki/Glosowanie.przez.internet-dlaczeg o.jeszcze.nie.w.Polsce.Korzysci.i.zagrozenia.zwiazane.z.wyborami.elektronicznym i,1383> accessed 30 June 2021. 
The question that remains to be answered is whether the above risks associated with e-voting therefore preclude its introduction? In answering this question, account must be taken, on the one hand, of these risks and, on the other, as the pandemic period in particular has shown, of the fact that modern man's life is moving online. This raises another question: how do banking operations differ from e-voting operations? After all, both of them are key to the functioning of societies, so they must use the highest security, and if banks can operate online, can't evoting? Although in theory the answer to the above seems simple, it is not. And it is also not true that bank security is the highest, because as the example of recent years shows, many banks have fallen victim to hackers. However, the difference between banking operations and e-voting is that while banks are businesses and can compensate for losses, e-voting is much worse, because democracy cannot be compensated for possibly rigged elections. Does this mean that there is no future for e-voting and concerns about its dangers will outweigh the desire to introduce it in Poland? In my opinion, no. E-voting is the future not only for Poland but also for the legal systems of other countries. The risk associated with it is high, but this does not mean that it cannot be minimised and I think that this is the right direction for change. 